\title{
13 \\ Colonisation and/or Cultural Contacts: A Discussion of the Western Micronesian Case
}

\author{
Michiko Intoh
}

\begin{abstract}
Archaeology, linguistic and genetic studies have demonstrated that the history of human dispersals into Micronesia was complex. The initial population movements into Micronesia involved the western island groups. Recent studies seem to have confirmed that the Mariana Islands were settled as early as 3500 BP, possibly from the Philippine Archipelago. Although no hard evidence has been found from Palau equivalent to this early date, it is possible that the western Micronesian islands were also colonised from Island Southeast Asia, before the rest of the Micronesian islands were settled around 2,000 years ago from Melanesia. This paper examines the next step following the initial settlements in Micronesia, based on the archaeological findings from Fais in the Central Caroline Islands. Continuous cultural contact between Fais and Yap from the initial colonisation period was confirmed by excavated Yapese potsherds and stones, as well as black rat (Rattus rattus) remains. In addition, extensive cultural contacts between Fais Islanders and a number of islands within and beyond Micronesia were also detected. For resource-limited coral islanders, the significance of having frequent interactions with other islands can be seen as one of their survival strategies. However, it is not a simple process to understand the background anthropological phenomena that explain how an exotic material was transferred from one island to another. Was it associated with a migrating population? Was it transported through exchange? Or was it created on the island using an exchange of knowledge? A complex interaction history will be demonstrated for this small raised coral island.
\end{abstract}

\section{Human dispersals into the Western Pacific}

Linguistic studies have shown that the major Austronesian movement was made from Taiwan, through the Philippine archipelago and Wallacea to the southwestern Pacific between about $4000 \mathrm{BP}$ and $3000 \mathrm{BP}$. The distinctive decorated pottery tradition, called Lapita, was associated with the earliest colonists to settle in Island Melanesia and western Polynesia (Kirch 1997).

Micronesia, on the other hand, has a complex history of human dispersals (e.g. Intoh 1997; Rainbird 2004). Malayo-Polynesian speakers from the Indonesian and Philippine archipelagos likely made the first movements into western Micronesia (i.e. the Marianas and Palau). The earliest dates of 3500 BP obtained from the Marianas (Bellwood 2011) are older than 
the earliest Lapita sites in Melanesia reported so far (Kirch 1997). Palau seems to have been settled later, possibly around 3000 BP (Clark 2005) followed by Yap, though the date of initial colonisation is still unclear (cf. Ross 1996; Dodson and Intoh 1999).

The next movements were made around 2,000 years ago from Melanesia to the central and eastern parts of Micronesia by Nuclear Micronesian speakers (Blust 1984). Archaeological evidence supporting this movement has been reported in the Marshalls, Kosrae, Pohnpei and Chuuk. Based on a few archaeological results most of the atolls in the Central Caroline Islands were likely settled around $1000 \mathrm{BP}$ (Rainbird 2004). ${ }^{1}$ The initial settlement of Fais Island was believed to have occurred during this movement. This was based on the linguistic evidence, prior to the archaeological research reported here. Polynesian-speaking peoples made a further movement to the atolls, of Nukuoro and Kapingamarangi. These are considered Polynesian outliers, as are some other Polynesian-speaking groups found in Melanesia.

Besides these major colonisation movements, there were a number of interactions among islands after initial settlement. Some of these interactions are well documented in the ethnographic records, such as the sawei exchange system between Yap and coral islands in the Central Caroline islands (Alkire 1965), and in the Marshall Islands (Weisler 1997).

\section{Archaeological research on Fais Island}

Fais is situated near the western end of the Central Caroline Islands extending from Ulithi to Namonuito (Figure 13.1). The nearest high island is Yap, about $180 \mathrm{~km}$ to the west. Fais Island is a raised coral island with a maximum height of $18 \mathrm{~m}$ above sea level. It is about $2.7 \mathrm{~km}$ in length and about $1.1 \mathrm{~km}$ in width and covers a land area of about $2.8 \mathrm{~km}^{2}$. The soil is rich in phosphate that provides a fertile environment for land subsistence; taro (Colocasia esculenta and Alocasia macrorrhiza), sweet potato, breadfruit, coconut, banana, and even yams are grown, though in a small quantity. Fishbone analysis has indicated that rich marine resources were also exploited (Ono and Intoh 2011).

It has become evident that the habitation on Fais Island was confined to the southern coastal flat throughout its history, and this is where the current villages are located.

1 Recently, an archaeological excavation showed that Mwoakilloa (Mokil) atoll in Eastern Micronesia was settled as early as 1700 1500 BP (Poteate et al. 2016). This data likewise the data from this paper indicates that the timing of settling small coral islands was slightly later but not considerably later than high islands nearby. 


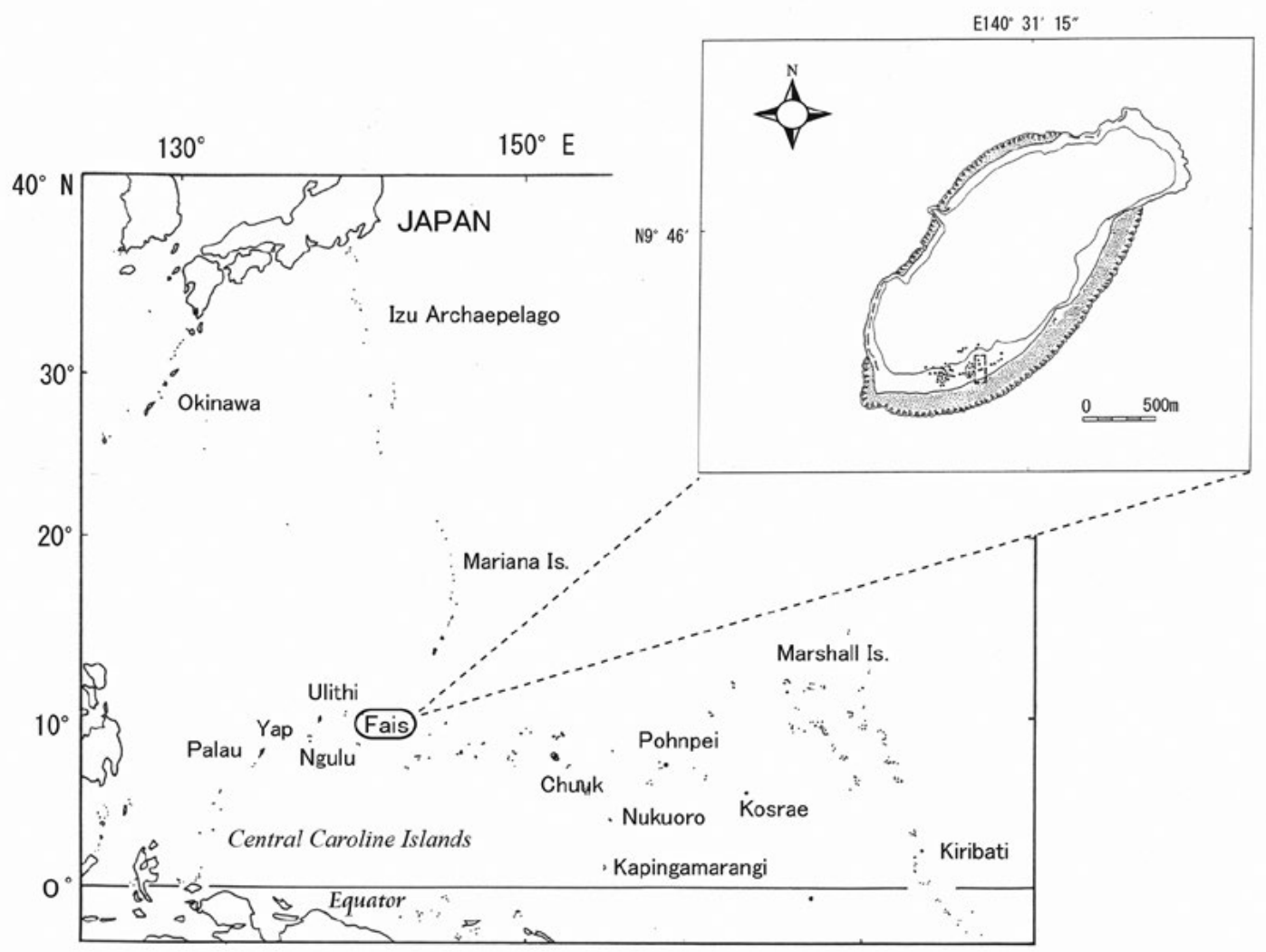

Figure 13.1 Map of Fais Island in Micronesia.

Source: M. Intoh.

\section{Cultural sequence of Fais Island}

Three seasons of archaeological excavation were undertaken on Fais. In 1991 and 2005, a deep cultural deposit, about $3.4 \mathrm{~m}$, was excavated on the southern coastal flat. The continuous distribution pattern of artefacts throughout the stratigraphic and sedimentary sequence indicates that Fais Island has been constantly inhabited since initial colonisation (Intoh 2008). The stratigraphy has been anchored to a radiometric chronology by $46{ }^{14} \mathrm{C}$ dates obtained on charcoal samples (Ono and Intoh 2011). The earliest date of 1965-1619 cal. BP (NUTA-2167) is the oldest reported thus far from the Central Caroline Islands. The 1994 research project concentrated on the proto-contact to post-contact cemetery, and a total of 13 inhumations were excavated (Lee et al. 2009).

Four cultural phases were set out according to the dates and changes in typology of the Yapese pottery recovered (Table 13.1).

Phase 1 starts right above the sterile white beach sand and dates between 1800-1600 cal. BP (this range was based upon four ${ }^{14} \mathrm{C}$ dates). This is the first colonisation period of Fais. Excavated materials include Yapese calcareous sand tempered (CST) potsherds, small amounts of Palauan plain pottery (characteristic buff-coloured surface with dark gray core), Yapese metamorphic stones, Tridacna shell adzes, various shell ornaments and faunal remains of pig, dog, chicken and rat (Intoh and Dickinson 2002; Steadman and Intoh 1994; Intoh and Shigehara 2004). These items constitute the basic artefact set found through all the cultural phases (Figure 13.2). The discovery of the three domesticated animals during the initial phases of colonisation was 
of especial significance because no other Micronesian islands, including volcanic islands, have produced evidence for simultaneous introduction of the pig, dog and chicken during initial island colonisation (see Intoh 1986; Rainbird 2004).

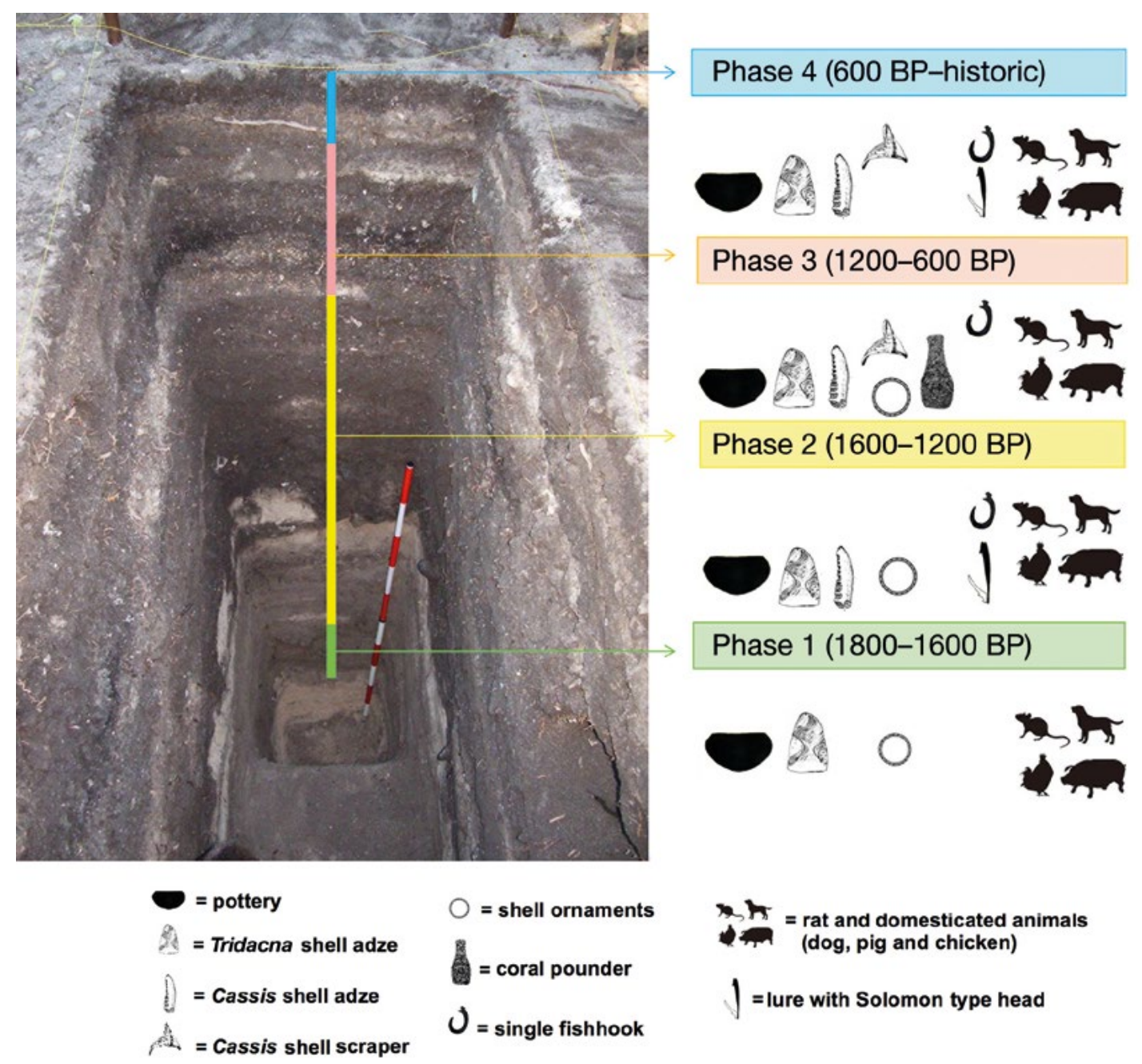

Figure 13.2 Summary diagram of excavated materials from Fais Island.

Source: M. Intoh.

From Phase 2 (1600-1200 BP), Cassis shell adzes and single fishhooks made of turtle carapace start to appear. A lure shank made of mother-of-pearl shell found in this phase has a head type typical of those found in the Solomons and known as the Solomon-types (Beasley 1928). As pearl shell is not available around the coasts of Fais, it is likely the lure was manufactured in the Solomon Islands and either brought directly to Fais or transported via eastern Micronesia where similar lures have been found (Weisler 2000). Another feature of the archaeological record from Phase 2 onwards is the appearance of fishhooks made of turtle carapace. Although the use of turtle carapace as a raw material in fishhook production is common in Oceania, the use of turtle carapace is very rare.

In Phase 3 (1200-600 BP), in addition to other common material culture, Cassis shell scrapers and a coral pounder for processing vegetable foods were found. No Solomon-type lures were recovered from this phase. 
In Phase 4 (600 BP to historic period) shell ornaments disappear from the archaeological record, except in the post-European-contact burial site where a number of shell ornaments were excavated in association with the inhumations. One young female, called SK-7, dated to $387 \pm 64 \mathrm{BP}$ (NUTA-4075), was buried with more than 300 tiny green glass beads (less than $2 \mathrm{~mm}$ in diameter) around her left wrist. Based on the extremely high lead content (more than 70 per cent) in the glass beads it is likely that they were manufactured in China. Beside these beads and two larger yellow Chinese lead glass beads, one unique Venetian bead (called a gooseberry bead) was also found. This particular type of Venetian bead is known to have been manufactured after seventeenth century (Smith 1983). It is reasonable to consider that these were brought from an area where glass beads of different origins co-existed, likely somewhere in Island Southeast Asia.

Table 13.1 Cultural phases of Fais Island based on radiometric dates on charcoal (cal. BP).

\begin{tabular}{|c|l|l|}
\hline Cultural Phase & FSFA-2 site (1991 research) & FSP0-3,4 site (2005 research) \\
\hline $\begin{array}{c}\text { IV } \\
(600 \text { BP-historic) }\end{array}$ & \multicolumn{2}{|l|}{} \\
\hline $\begin{array}{c}\text { III } \\
(1200-600 ~ B P)\end{array}$ & $2(877-665)$ Wk-3564 & \\
\cline { 2 - 3 } $\begin{array}{c}\text { II } \\
(1600-1200 ~ B P)\end{array}$ & $3(910-693)$ NZ-7884 & $6(750-660)$ Beta-213064 \\
\cline { 2 - 3 } & $4(1491-1290)$ NUTA-2163 & $8(1320-1240)$ Beta-213063 \\
\hline & & $10(1530-1340)$ Beta-22149 \\
\hline \multirow{2}{*}{$\begin{array}{c}\text { I } \\
(1800-1600 ~ B P)\end{array}$} & & $11(1540-1350)$ Beta-213062 \\
\hline & $5(1862-1544)$ NZ-7885 & $11(1530-1340)$ Beta-237516 \\
\hline & $6(1915-1569)$ NUTA-2167 & $12(1710-1530)$ Beta-213061 \\
\hline
\end{tabular}

Source: M. Intoh.

\section{Colonisation and interaction}

\section{Colonisation of Fais Island}

The rich excavated material culture found in Phase 1 includes various imported artefacts and domestic animals from different origins. These can be divided into two groups according to the directionality of movement from point of origin to Fais.

From the west is a group of artefacts including pottery and metamorphic stones from Yap, and a small number of ceramics from Palau. It is possible that pottery was brought directly from Palau. However, the inclusion of material culture from Yap raises the possibility that the Palauan pottery was traded down the line to Fais via Yap where some Palauan potsherds have also been excavated (Intoh and Leach 1985; Intoh 1990a, 1990b).

Besides domesticated animals, rat (Rattus sp.) originally identified by White and Flannery (n.d.) as $R$. tanezumi was also brought to Fais. This type of rat is not found in either Melanesia or Polynesia, but is widely distributed across Southeast Asia and Micronesia. As the rat remains were found from the bottom of the earliest cultural layer together with Yapese CST potsherds, it is very likely that rats were introduced to Fais by some of the earliest colonists to arrive from Yap.

Although pigs, dogs and chickens were all introduced to the Pacific from ISEA during colonisation by Austronesian-speaking populations (Bellwood 2011), there are very few prehistoric locations where all three are found together (Cassels 1983). There are no records of the three together 
anywhere in Micronesia, only dogs are found in the Eastern Caroline Islands and sporadic pig remains from Palau have been reported (Intoh 1986; Masse et al. 2006). Thus, it is very likely that domesticates were introduced to Fais from outside Micronesia, possibly from Melanesia, or directly from Southeast Asia.

The archaeological evidence suggests three different colonisation scenarios: one that brought colonists from Yap, or from the Melanesian islands, or from both, to Fais. None of these proposed scenarios based on the archaeological record corresponds to the linguistic data that proposes a migration and colonisation of Fais from the east by speakers of Nuclear Micronesian (see Jackson 1986; Pawley and Ross 1995). The Fais example emphasises caution when applying contemporary linguistic evidence to understand human movements and colonisation history, especially when it occurred almost 1,800 years ago.

\section{Active interactions}

From Phase 2 onwards, changes in the morphology of imported Fais pottery reflect similar changes within the same timeframes on Yap (Intoh 1990a, 1990b). This would suggest continuing contact between Fais and Yap. Domestic animals are also continuously represented throughout the archaeological sequences. Giovas (2006) has noted that there is high probability of pig extinctions on islands, at least in Polynesia, if island size is less than $11.64 \mathrm{~km}^{2}$. This is possibly due to the perceived unsustainability of maintaining pig populations on resource-impoverished islands over the long term, and pig populations were either allowed to die out or deliberately exterminated. Does this then lend itself to the possibility that pigs were introduced to Fais more than once from Melanesia? The answer is that it is unlikely, because the recent strontium isotope study of excavated pig teeth strongly indicates that pigs on Fais were not raised within a volcanic environment, such as those that exist on Yap or Pohnpei, or common in Melanesia, but rather they spent their entire lives in a coral island environment (Gakuhari et al. 2013). This would suggest that the inhabitants of Fais found some way to maintain pig populations within a small island environment.

On the other hand, studies of ancient mitochondrial DNA (mtDNA) recovered from the excavated skeletal material on Fais support the linguistic data. Shinoda and Intoh (2012) succeeded in recovering mitochondrial DNA sequences from five skeletons dated from ca. 500 BP to 600 BP. Two samples contained the so-called Polynesian motif (haplogroup B4a1a1a), and one sample contained its ancestral haplogroup (B4a1a1). This suggests that at least some of the late prehistoric Fais Islanders came through Melanesia, either directly, or through eastern Micronesia.

There are also several new cultural elements introduced to Fais from various directions. For example, the Solomon-type pearl shell lure suggests either direct contact between the Solomons and Fais, or indirect transmission through the Eastern Caroline Islands (see Weisler 2000).

A weaving tradition in the proto-historic period was distributed widely among the Central Caroline coral islands and Polynesian outliers in Micronesia, but did not extend as far as western Micronesia. This rather narrow geographic distribution is similar to that of other cultural traits in the region, such as kite fishing. As the distribution of these traditions in Micronesia roughly corresponds to that of Nuclear Micronesian speakers in the coral islands, it is most likely that these cultural traditions were dispersed by inter-island transactions possibly after accidental contacts with eastern Indonesia where these traditions were also practised. 


\section{Discussion and conclusion}

Combining the archaeological and ancient genetic data provides an overview of the complex prehistoric interactions between Fais and surrounding islands and archipelagos. It demonstrates strong and enduring connections between Fais and Yap, from initial colonisation between 1800-1600 BP until the historic period. The archaeological record also indicates contact with Melanesia, the likely source of the domesticated pig, dog and chicken that had arrived in the region during the Austronesian expansion. In contrast, the linguistics suggests an origin for the Fais Islanders from the east where Nuclear Micronesian languages are spoken. The problem is that none of these islands are known to have possessed domesticated animals except for dogs. Historical information indicates a later introduction of some Indonesian cultural traits, possibly through interactions with other coral islanders.

Where did the original Fais islanders originate? There are three possibilities to consider:

1. The Yapese originally colonised Fais, bringing with them pottery and rats. If so, then soon after initial settlement domestic pigs, dogs and chickens were obtained from Melanesia. This would have necessitated a round-trip voyage from Fais to somewhere in Melanesia because there is currently no evidence of people on the islands in between before $1000 \mathrm{BP}$.

2. Melanesians who brought with them domesticated pigs, dogs and chickens initially colonised Fais. If so, then shortly after initial settlement members of the founding population travelled to Yap, returning with pots and rats. This pattern of contact is somewhat different from the general colonisation strategy observed in other parts of Oceania, where the colonists kept contact with their place of origin for some time until settlement was solidly established and viable on the newly colonised island.

3. Between 1800-1600 BP populations arrived from both Yap and Melanesia on Fais. If so, then these peoples would have brought with them different cultural traditions, material cultures and domestic animals. The languages first spoken on Fais by the colonists from Yap and/or Melanesia must have been replaced by Nuclear Micronesian (Ross 1996).

Currently, either 2 or 3 seem most plausible. In the archaeological excavations, however, a small amount of Yapese pottery and rat bones were recovered from greater depth, and are possibly earlier than the appearance of domestic animals in the chronological sequence of Fais. But records of pigs, dogs and chickens in Phase 1 suggest their arrival was not more than two centuries after initial colonisation. If so, it is possible that the founding population of Fais had a dual origin and language replacement occurred early in Fais history. Detailed results will be published in a few years' time.

Besides the major colonisation movements, it has clearly been shown in this study that active interactions without formal exchange relations were widely practised within and beyond Micronesia. We should be careful not to confuse such interactions with colonisation movements.

\section{Acknowledgements}

I would like to express my sincere appreciation to the people of Fais and Yap Historic Preservation Office for providing me with the opportunity to excavate their island. I owe many thanks to the following specialists and colleagues: D. Rubinstein, W. Dickinson, K. Katayama, K. Shinoda, P. White, T. Flannery, D. Steadman, A. Storey, F. Leach, J. Davidson, R. Ono, M. Yoneda, T. Gakuhari and N. Shigehara.

This study is supported in part by KAKENHI in 2011-2015 (no. 23247040) from the Japan Society for the Promotion of Science (JSPS). 


\section{References}

Alkire, W.H. 1965. Lamotrek Atoll and Inter-Island Socioeconomic Ties. Urbana: University of Illinois Press.

Beasley, H.G. 1928. Fishhooks. Pacific Island Records, London: John Hewett.

Bellwood, P. 2011. Holocene population history in the Pacific region as a model for worldwide food producer dispersals. Current Anthropology 52(4): S363-S378. doi.org/10.1086/658181.

Blust, R. 1984. Malaita-Micronesian: A eastern Oceanic subgroup? The Journal of the Polynesian Society 93: 99-140.

Cassels, R. 1983. Prehistoric man and animals in Australia and Oceania. In L.J. Peel and D.E. Tribe (eds), Domestication, Conservation and Use of Animal Resources, pp. 41-62. Amsterdam: Elsevier.

Clark, G.R. 2005. A 3000-year culture sequence from Palau, western Micronesia. Asian Perspectives 44(2): 349-380. doi.org/10.1353/asi.2005.0020.

Dodson, J.R. and M. Intoh. 1999. Prehistory and palaeoecology of Yap, Federated States of Micronesia. Quaternary International 59: 17-26. doi.org/10.1016/S1040-6182(98)00068-8.

Gakuhari, T., M. Intoh, T. Nakano and M. Yoneda. 2013. Strontium isotope analysis of prehistoric faunal remains excavated from Fais Island in Micronesia. People and Culture in Oceania 29: 69-81.

Giovas, C. 2006. No pig atoll: Island biogeography and the extirpation of a Polynesian domesticate. Asian Perspectives 45(1): 69-95. doi.org/10.1353/asi.2006.0004.

Intoh, M. 1986. Pigs in Micronesia: Introduction or re-introduction by the Europeans. Man and Culture in Oceania 2: 1-26.

1990a. Changing Prehistoric Yapese Pottery Technology: A Case Study of Adaptive Transformation. Michigan: UMI Press.

1990b. Ceramic environment and technology: A case study in the Yap islands in Micronesia. Man and Culture in Oceania 6: 35-52.

1997. Human dispersals into Micronesia. Anthropological Science 105: 15-28. doi.org/10.1537/ ase.105.15.

- 2008. Ongoing archaeological research on Fais island, Micronesia. Asian Perspectives 47: 121-138. doi.org/10.1353/asi.2008.0000.

Intoh, M. and W.R. Dickinson. 2002. Prehistoric pottery movements in western Micronesia: Technological and petrological study of potsherds from Fais island. In S. Bedford, C. Sand and D. Burley (eds), Fifty Years in the Field: Essays in Honour and Celebration of Richard Shutler Jr.'s Archaeological Career, pp. 123-134. Auckland: New Zealand Archaeological Association.

Intoh, M. and B.F. Leach. 1985. Archaeological Investigations in the Yap Islands, Micronesia: First Millennium B.P. to the Present Day. Oxford: BAR.

Intoh M. and N. Shigehara. 2004. Prehistoric pig and dog remains from Fais island, Micronesia. Anthropological Science 112: 257-267. doi.org/10.1537/ase.040511.

Jackson, F.H. 1986. On determining the external relationships of the Micronesian languages. In P. Garaghty, L. Carrington and S.A. Wurm (eds), FOCAL II: Papers from the Fourth International Conference on Austronesian Linguistics (PL C-94). pp. 201-238. 
Kirch, P.V. 1997. The Lapita Peoples: Ancestors of the Oceanic World. Massachusetts: Blackwell.

Lee, A.L., K. Katayama and M. Intoh. 2009. Morphological examination of the human skeletal remains from Fais Island, Federated States of Micronesia. People and Culture in Oceania 25: 53-84.

Masse, W.B., J. Liston, J. Carucci, and J.S. Athens. 2006. Evaluating the effects of climate change on environment, resource depletion, and culture in the Palau Islands between AD 1200 and 1600. Quaternary International 151: 106-132. doi.org/10.1016/j.quaint.2006.01.017.

Ono, R. and M. Intoh. 2011. Island of pelagic fishermen: Temporal changes in prehistoric fishing on Fais, Micronesia. Journal of Island and Coastal Archaeology 6(2): 255-286. doi.org/10.1080/1556489 4.2010.540531.

Pawley, A. and M. Ross. 1995. The prehistory of the Oceanic languages: A current view. In P. Bellwood, J.J. Fox and D. Tryon (eds), The Austronesians: Historical and Comparative Perspectives, pp. 39-74. Canberra: The Australian National University.

Poteate, A.S., S.M Fitzpatrick, W.S. Ayres and A. Thompson. 2016. First radiocarbon chronology for Mwoakilloa (Mokil) Atoll, Eastern Caroline Islands, Micronesia. Radiocarbon 58: 169-178. doi. org/10.1017/RDC.2015.16.

Rainbird, P. 2004. The Archaeology of Micronesia. Cambridge: Cambridge University Press. doi. org/10.1017/CBO9780511616952.

Ross, M. 1996. Is Yapese Oceanic? In B. Nothofer (ed.), Reconstruction, Classifcation, Description: Festschrift in Honor of Isidore Dyen, pp. 121-166. Asia-Pacific Abera Network, vol. 3. Hamburg: Abera Verlag.

Shinoda, K. and M. Intoh. 2012. Analysis of the mtDNA of human skeletal remains excavated from Fais Island, Micronesia. Anthropological Science 120(3): 261.

Smith, M.T. 1983. Chronology from glass beads: The Spanish Period in the Southeast, 1513-1670. In C.F. Hayes III (ed.), Proceedings of the 1982 Glass Trade Bead Conference, pp. 147-158. Research Records 16, NY: Rochester Museum and Science Center.

Steadman, D.W. and M. Intoh. 1994. Biogeography and prehistoric exploitation of birds from Fais Island, Yap State, Federated States of Micronesia. Pacific Science 48: 116-135.

Weisler, M. (ed.). 1997. Prehistoric Long-Distance Interaction in Oceania: An Interdisciplinary Approach. Auckland: New Zealand Archaeological Association.

- 2000. Burial artifacts from the Marshall Islands: description, dating and evidence for extraarchipelago contacts. Micronesica 33(1/2): 111-136.

White, J.P. and T. Flannery. n.d. Murids from Fais Island. Unpublished manuscript. 
This text is taken from New Perspectives in Southeast Asian and Pacific Prehistory, edited by Philip J. Piper, Hirofumi Matsumura and David Bulbeck, published 2017 by ANU Press, The Australian National University, Canberra, Australia. 